\title{
Open Innovation: A Study of Industry-University Collaboration in Environmental R\&D in Hong Kong
}

\author{
Jacqueline Chi Kei Lam, The University of Hong Kong, China \\ Peter Hills, The University of Hong Kong, China \\ Clever K.W. Ng, The University of Hong Kong, China
}

\begin{abstract}
Innovation plays a key role in driving industries to gain competitive advantage. Increasingly, open innovation is considered a key driver to help industries accelerate the rate of innovation through exploitation of the free flow of internal and external knowledge and expertise. With the external input of expertise and knowledge, industries can acquire stronger capability for innovation, and achieve better competitiveness than those which rely only on traditional closed innovation approach. Industries, especially small and medium enterprises, are particularly interested in partnering with universities as niche collaborators due to their innovation competence. In face of intensive global competition, university-industry collaboration has been advocated by the government as a form of open innovation to enhance the development and commercialization of niche technologies for the environment. In 2009-2010, Hong Kong ranked 3rd in Global Innovation Index, out of 132 economies surveyed. In terms of university-industry collaboration, Hong Kong ranked 27. To gain a deeper understanding of what de-termines industry-university innovation, this study focusses on all cleaner energy and environ-mentaloriented Innovation-and-Technology (ITF) funded projects that have been approved since the establishment of Hong Kong Innovation and Technology Fund in 1999 and that have involved university-industry collaboration. A total of 145 out of 2,345 ITF funded projects that carry the theme of cleaner energy and environment research and development during 1999-2010 have been selected. Quantitative surveys and qualitative face-to-face interviews have been conducted to identify what drivers and barriers for this group of ITF industries are involved in their engagement in industry-university collaboration, and why these drivers and barriers exist. The results obtained show that majority of the local industries surveyed and interviewed are eager to collaborate with universities in environmental innovation for competitive advantage, especially for gaining reputations and securing future business opportunities. However, huge obstacles exist for local industries to partner with universities, especially for the SMEs, due to policy and institutional constraints. Innovation policies in support of SME innovation and institutional mechanisms to help SMEs find the right university partners are particularly relevant and critical for promoting open innovation (in the form of university-industry collaboration) in environmental and cleaner energy research among local industries in future.
\end{abstract}

Keywords: Open Innovation, Driver, Barrier, Innovation Policy, Industry-University Collaboration, Environment, Research and Development, Innovation and Technology Funded Projects, Hong Kong

The International Journal of Technology, Knowledge, and Society

Volume 8, 2012, http://techandsoc.com/, ISSN 1832-3669

(C) Common Ground, Jacqueline Chi Kei Lam, Peter Hills, Clever K.W. Ng, All Rights Reserved, Permissions: cg-support@commongroundpublishing.com 


\section{INTRODUCTION}

I

n many countries, innovation plays a key role in driving industries and businesses to gain competitive advantage (Porter, 1998). Increasingly, open innovation is considered a key driver in helping industries accelerate the rate of innovation through exploitation of the free flow of internal and external knowledge and expertise. With external input of expertise and knowledge, industries are more likely to acquire a stronger capability for innovation, thus achieving higher industrial competitiveness than those which rely only on traditional closed innovation approach (Chesbourgh, 2003). Industry-University Collaboration (IUC) is considered a form of open innovation. Industries, especially small and medium enterprises (SMEs), look to university collaborators for the needed innovation competence that they lack through partnership (Schienstock and Hämäläinen, 2009).

In face of intensive competition from other competitors in the region such as Shenzhen, Shanghai, Beijing and Singapore, Hong Kong has increasingly perceived the need to achieve economic competitiveness through innovation. IUC has been advocated by the government as an effective means for innovation, especially for developing and commercializing niche technologies in various domains, including the environment (Invest HK, 2011). In 2009-2010, Hong Kong ranked third in the Global Innovation Index out of 132 economies surveyed. In terms of university-industry collaboration, Hong Kong ranked twenty-seven (Insead, 2010). It would thus be interesting to examine the drivers and barriers for industries to engage in IUC in Hong Kong. This study will look at one of the government-selected industries for innovation, the environmental industry, and identify ways to further enhance the sector's technology and innovation competence by means of open innovation-IUC, thereby contributing to enhancing Hong Kong's economic competitiveness in the long term.

IUC has been used as a strategy by industries/universities to enhance the process of innovation. In general, the key drivers to IUC include the economics of innovation: rising costs of production and decreasing revenues from closed innovation (Chesbourgh et al., 2006; Melese et al., 2009); reputation management (Fontana et al., 2006); government policies and incentives (Van Looy et al., 2003; Hershberg et al., 2007); openness culture (Van Looy et al., 2003; Laursen and Salter, 2004; Fontana et al., 2006); and reliance on university for expertise and equipment for enhancing internal R\&D capability (Fontana et al., 2006; Melese et al. 2009). The key barriers to IUC include fear of disclosure of important business information to third parties (Melese et al., 2009), and cultural, norm and value gaps between industries and universities (Fontana et al., 2006; Melese et al., 2009) For instance, industry and university may have different research objectives/foci. Some industries may find it difficult to cope with the open innovation culture, the lack of coordinating/bridging mechanisms (collaboration ad-hoc and opportunistic, often based on personal relationships), duration of innovation involved (Melese et al., 2009), and problems associated with the distribution and sharing of resources (e.g. budgeting and staffing) (Melese et al., 2009).

Other firm characteristics also affect companies' involvement in IUC. Company size, innovation intensity, and the nature of company business have an impact on IUC. Companies with a higher dependence on science or engineering, e.g. pharmaceutical or nanotechnology firms, carry a better track record of IUC (Laursen and Salter, 2004; Fontana et al., 2006; Perkmann and Walsh, 2007). This is the same with companies that have a higher R\&D intensity (Lausen and Salter, 2004; Fontana et al., 2006) and larger firm size (Fontana et al., 2006). To date, successful cases of open innovation are limited to multinational companies and advanced technology companies with a considerable company size and capital in the global context (Chesbourgh, 2003; Herzdog, 2009). Not much work has been done on green technologies and the potential of IUC to enhance local industries' competitive advantage. This study intends to close the research gap. 


\section{Methodology}

To understand the drivers and barriers pertaining to IUC in Hong Kong, this research study was conducted with industry participants who have successfully obtained project funding from the Hong Kong Innovation-and-Technology Fund for university-industry collaboration during the period of 1999-2011. As of October 2010, a total of 145 out of 2345 ITF funded projects fall into the environmental category, 89 of them being IUC. $29 \%$ of the 89 projects are energyrelated, and within this category, $27 \%$ are related to renewable energy (see Figure 1).

\section{Composition of Industry-University Collaborative ITF- funded Environmental Projects}

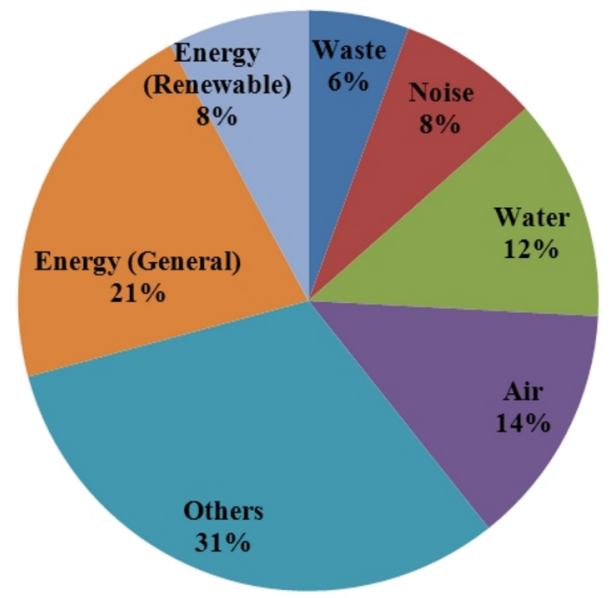

Figure 1: Composition of Industry-University Collaborative ITF-funded Environmental Projects

To identify the key drivers and barriers for industries to take part in IUC and the types of IUC that these parties have established, an online-quantitative survey was distributed during October 2010-March 2011 to all coordinators/deputy coordinators of the companies who partnered with universities in environmental-related funded projects. A total of 16 companies have completed the online-questionnaire. The response rate is $18 \%$. To gain a deeper understanding of how these drivers/barriers influence UIC and how open innovation affects the company's competitive advantage, we have conducted qualitative face-to-face interviews. 4 companies, including 2 large and 2 SME companies, have been selected for interviews.

Table 1 summarizes the details of the 16 respondents who completed the survey and responded to our interview. The respondents are top decision-makers of their companies, nor- mally in charge of the R\&D team, and project coordinators/deputy project coordinators of the ITFfunded environmental projects. Of the 16 companies surveyed, the majority of the companies are SMEs. 10 of them have no more than 50 research and non-research personnel. Only 2 companies hire more than 150 staff (including research and non-research staff). They are classified as large companies. The amount of funding for the ITF projects ranged from $\$ 165,000$ to $\$ 3,400,000$. The environmental topics cover air, water, waste, energy, climate change, material science, and environmental health and safety. Among the 16 companies surveyed, interviews have been conducted to 4 companies. 
Table 1: Profiles of the ITF-funded Companies Surveyed and Interviewed

\begin{tabular}{|c|c|c|c|c|}
\hline Nature & Programme & Funded Amount (HK\$) & No. of Employees & $\begin{array}{c}\text { Survey (S)/ } \\
\text { Interview (I) }\end{array}$ \\
\hline Noise & UICP & 165,000 & $>200$ & $\mathrm{~S}+\mathrm{I}$ \\
\hline Others-Material & ITSP & $1,050,000$ & $150-200$ & $\mathrm{~S}+\mathrm{I}$ \\
\hline Energy & ITSP & 828,000 & $<50$ & $\mathrm{~S}+\mathrm{I}$ \\
\hline Waste & SERAP & $2,000,000$ & $<50$ & $S$ \\
\hline Noise & SERAP & $1,331,000$ & $<50$ & $S$ \\
\hline Waste/Energy & SERAP & $2,655,000$ & $<50$ & $S$ \\
\hline Energy & SERAP & 347,000 & $<50$ & $S$ \\
\hline $\begin{array}{l}\text { Others-Carbon } \\
\text { Reduction Plant }\end{array}$ & SERAP & 382,000 & $<50$ & $\mathrm{~S}+\mathrm{I}$ \\
\hline $\begin{array}{l}\text { Others-EHS } \\
\text { Material }\end{array}$ & SERAP & 639,000 & $<50$ & $S$ \\
\hline Air & SERAP & $1,644,000$ & $<50$ & $S$ \\
\hline Water & SERAP & 128,000 & $<50$ & $S$ \\
\hline Waste & SERAP & $2,000,000$ & $<50$ & $S$ \\
\hline Air & SERAP & 747,000 & $<50$ & $S$ \\
\hline Energy & SERAP & $1,217,000$ & $<50$ & $S$ \\
\hline Water & SERAP & 890,000 & $<50$ & $S$ \\
\hline Waste & ITSP & $3,400,000$ & $>200$ & $S$ \\
\hline \multicolumn{5}{|c|}{$\begin{aligned} & \text { Key: UICP }=\text { University-Industry Collaboration Programme } \\
& \text { ITSP }=\text { Innovation and Technology Support Programme } \\
& \text { SERAP }=\text { Small Entrepreneur Research Assistance Progra }\end{aligned}$} \\
\hline
\end{tabular}

\section{Survey Results: Drivers and Barriers to IUC for Environmental ITF-funded Projects in Hong Kong}

The survey attempts to understand the key barriers and drivers affecting decisions of industries involved in ITF-funded environmental projects to collaborate with university partners, the form of IUC they have established, and what areas of competitive advantage these IUC open innovation environmental projects bring to their companies.

A question was raised concerning the key drivers for the ITF-funded industries to adopt IUC for their environmental projects. Among all respondents, "innovative and unique business model with the potential to increase our company's competitive advantage" topped the list of key drivers for companies to adopt IUC (Mean Score $=4.5$ ), followed by "technology complexity and integration" (Mean Score $=4.1$ ). In addition, "pressure to produce more innovative and user-friendly products due to increasing customer demands", and "reputation management" were among the second-tier drivers to IUC" (Mean Score = 3.9). There were, however, very few motivations for the surveyed companies to engage in IUC for ITF-funded environmental projects for the sake of skill and knowledge leveraging, compliance with strict environmental standards (see Figure 2). Other additional drivers cited by the surveyed companies included: 
same mission and interests with external partner, and the need to look for external funding and resource support due to limited support from the government for innovation and corporate social responsibility.

\section{Key Drivers for Industries to Collaborate with Universities}

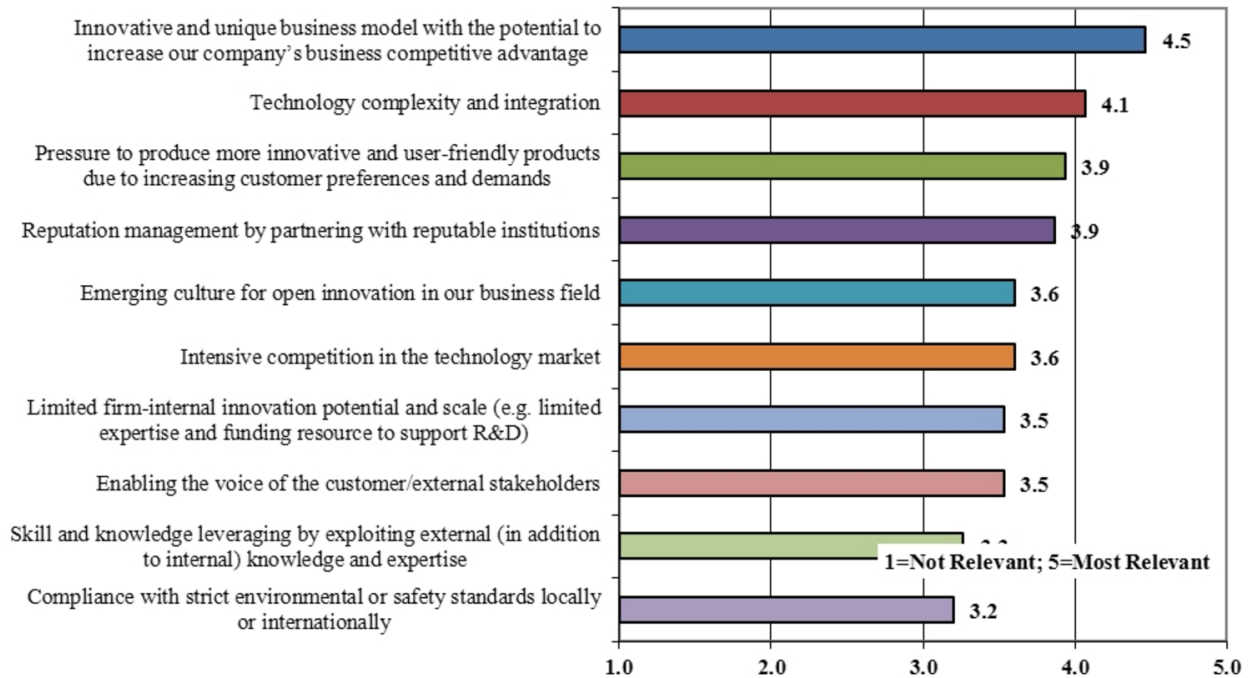

Figure 2: Key Drivers for Industries Engaging in ITF-funded Environmental Projects to Collaborate with Universities

The participants were also asked for the key barriers to adopt IUC open-innovation in their ITF-funded environmental projects. The majority of companies revealed in the survey that the unavailability of competent external partners to provide the necessary knowledge and technologies is the key barrier $(50 \%)$. The fear of disclosing their own intellectual property to external partners was rated as the second key barrier $(44 \%)$. About one third of the companies considered innovation too easy to copy, or lack of demands from clients/customers for generation of knowledge and technologies that are more client responsive as the barriers $(31 \%)$. One fourth of the companies considered difficulty in integrating external knowledge and technologies with existing firm-internal ideas and technologies, higher uncertainty and unpredictability concerning the overall planning and implementation of IUC projects, or strong internal competence as key barriers. Only $13 \%$ of the companies thought that the absence of corporate policies to incorporate external ideas is a key barrier. Interestingly, no companies considered that existing legislation, norms and regulations discouraged IUC. Nor was corporate management's resistance to involving external parties a barrier to IUC (see Figure 3). For some companies, innovation was considered a rather easy task and they did not think they had to rely on external partners to achieve the target. Others citied the lack of manpower to oversee, and lack of government support as key barriers to IUC. 


\section{Key Barriers for Industries to Collaborate With Universities}

Unavailability of competent external partners to provide the necessary knowledge and technologies for open innovation

Fear of disclosure of our own intellectual property to extemal partners

Innovation too easy to copy, no need to rely on extemal parties for knowledge and technologies

Lack of demands from clients and customers for generation of knowledge and technologies that are more client/user responsive

Difficulty in integrating extemal knowledge and technologies with existing firm-intemal ideas and technologies

Higher uncertainty and unpredictability conceming the overallplanning and implementation of open innovation projects

Strong internal competence, no need to rely on external knowledge and technologies for business competitiveness

Absence of corporate policies to incorporate extemal ideas

Existing legislation, norms, regulations and standards do not encourage open innovation

Resistance to including external parties by corporate management

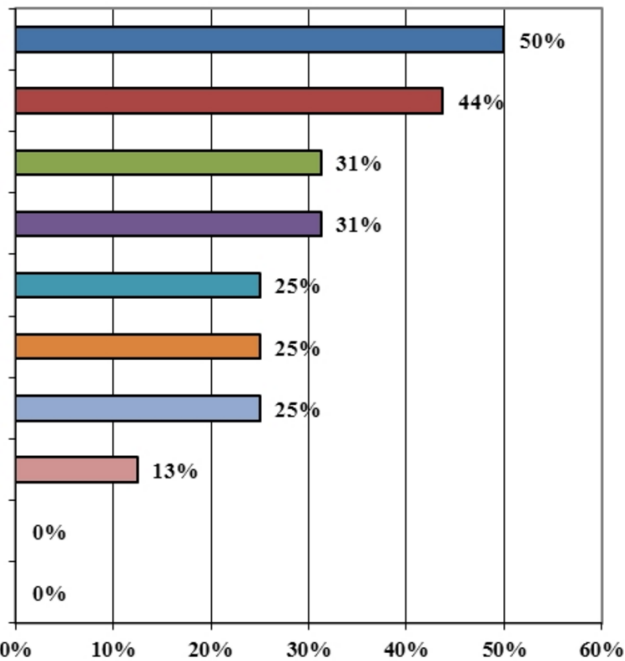

Figure 3: Key Barriers for Industries to Collaborate with Universities

An important question was raised: Has the open innovation approach in the form of IUC led to higher competitive advantage? A strong view was held by the surveyed companies regarding the overall enhancement of company competitive advantage as a result of collaboration with university partners on ITF-funded environmental projects (Mean Score $=4.2$ ). The group of companies strongly believed that an open innovation approach can lead to higher profitability of open innovation products and services (Mean Score $=4.00$ ) as well as innovation competence (Mean Score $=4.00)$. Companies held moderately strong views regarding the following aspects of competitive advantage as a result of engaging in IUC, including: user/customer satisfaction $($ Mean Score $=3.87)$; reputation management $($ Mean Score $=3.60)$; whereas companies tended to remain neutral with regard to the views that engaging in IUC would be cost-saving (Mean Score $=3.47$ ) and would help them outcompete industry/business partners (Mean Score $=3.40$ ) (see Figure 4). 


\section{Aspects of Competitive Advantage Achieved by Companies After Engaging in Industry-University Collaboration}

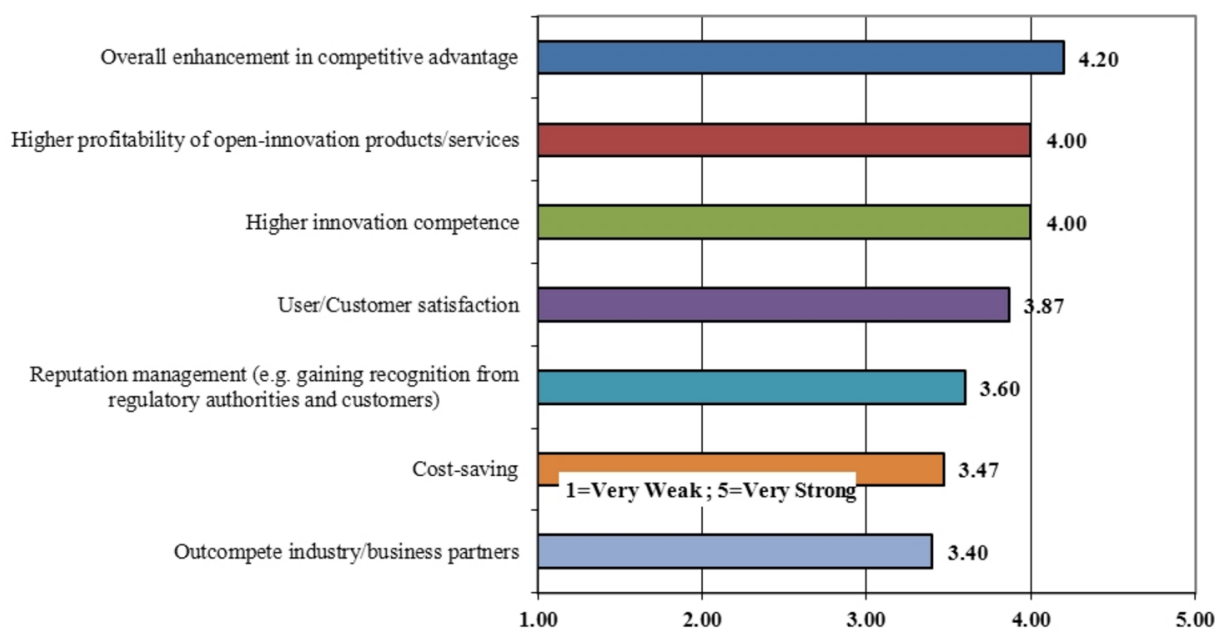

Figure 4: Aspects of Competitive Advantage Achieved by Companies after Engaging in Industry-University Collaboration

It would be interesting to understand what means of collaboration the companies engaged in ITF-funded environmental projects had established with their collaborators. The use of codified scientific knowledge accessible through scientific publications, conferences and networking with collaborator; integration of users' feedback $(47 \%)$, inter-organizational arrangements for pursuing collaborative R\&D (47\%), and commissioned contract research $(40 \%)$, seemed to be the most preferred options. Informal interaction $(27 \%)$ and human resource transfer $(20 \%)$ were the least employed options. No surveyed companies so far developed collaboration with universities through a company they partly own with their collaborator (see Figure 5). 


\section{Means of Industry-University Collaboration}

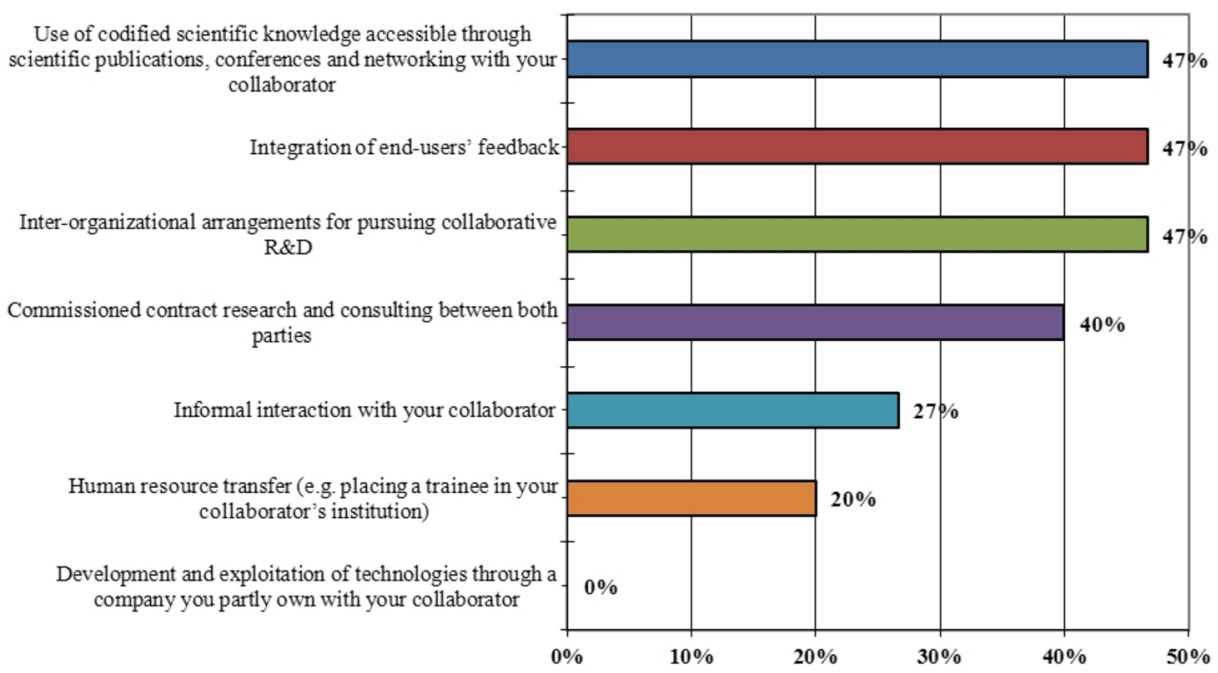

Figure 5: Means of Industry-University Collaboration

Finally, concerning the external collaborators whom the ITF-funded companies would frequently rely upon and be considered as important sources for generating ideas or innovations, it is interesting to note that customers was the most frequently relied and most important external source of ideas and innovations (Mean Score $=3.5$ ), followed by lawmakers/regulations (Mean Score $=3.1$ ), universities or engineers/consultants (Mean Score $=2.9$ ), research institutes (Mean Score $=2.7$ ). Although these surveyed companies had all partnered with universities on ITFfunded environmental projects, universities were not considered by these companies a favorite source for ideas generation and innovations (see Figure 6). 


\section{Reliance on External Sources for Ideas and Innovations}

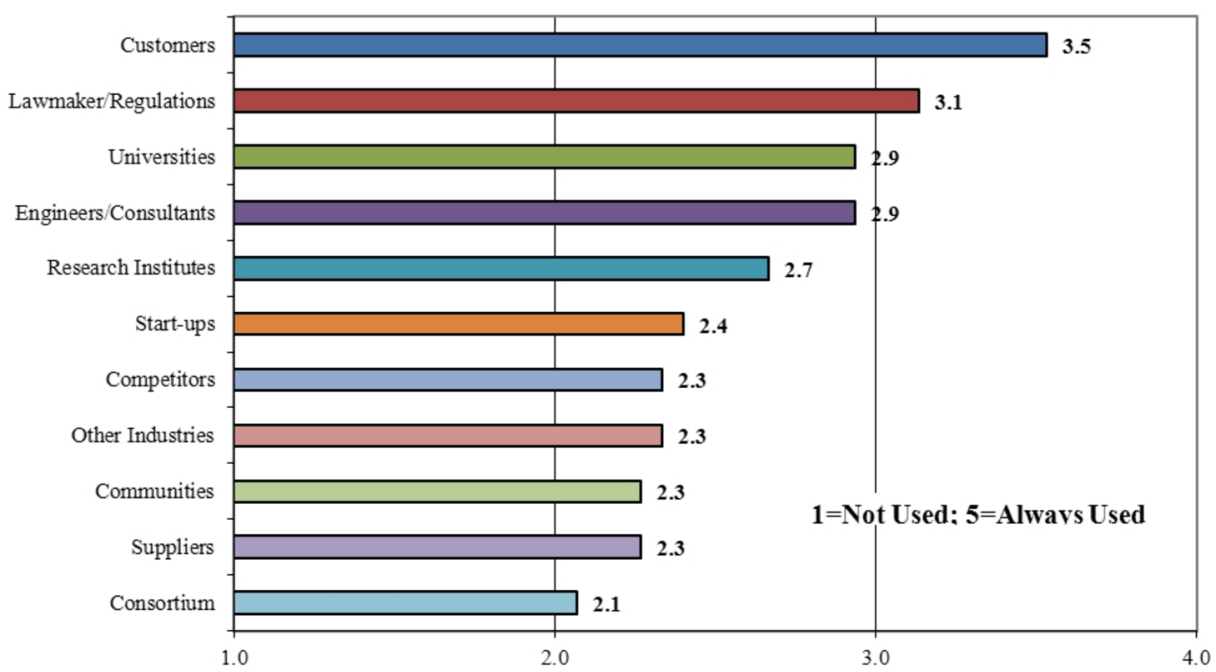

Figure 6: Reliance on External Sources for Ideas and Innovations

\section{Interview Results: Drivers and Barriers to IUC for Environmental ITF-funded Projects in Hong Kong}

Five questions were asked to solicit respondents' views regarding the IUC in two large and small companies. These include: stage at which innovation is applied, key drivers and barriers to open innovation in the form of IUC, motivators for IUC, as well as the size and scale impact on the company's capability to conduct IUC. The companies were engaged in IUC environmental innovation projects in the areas of cleaner energy and carbon reduction. Table 2 summarizes the profiles of the four companies interviewed. Large companies refer to companies with a company size of more than 50 employees. Small companies are characterized by companies which own less than 50 employees. Below details the results of the interview with these four companies. For further details, please find from Appendix A. 
Table 2: Profiles of Interviewed Companies

\begin{tabular}{|l|l|l|l|c|c|}
\hline Company & $\begin{array}{l}\text { IUC Project } \\
\text { Focus }\end{array}$ & $\begin{array}{l}\text { Position } \\
\text { Category }\end{array}$ & $\begin{array}{c}\text { Funded } \\
\text { Amount } \\
\text { (HK\$) }\end{array}$ & $\begin{array}{c}\text { No. of } \\
\text { Employees }\end{array}$ \\
\hline A & $\begin{array}{l}\text { Development of } \\
\text { Noise-reduction } \\
\text { Technology }\end{array}$ & $\begin{array}{l}\text { R\&D Senior Dir- } \\
\text { ector (Project Co- } \\
\text { ordinator) }\end{array}$ & UICP & 165,000 & $>200$ \\
\hline B & $\begin{array}{l}\text { Replacement of in- } \\
\text { organic, health -risk } \\
\text { material with organ- } \\
\text { ic, environmentally- } \\
\text { friendly material }\end{array}$ & $\begin{array}{l}\text { Strategic Manager } \\
\text { (Deputy Project } \\
\text { Coordinator) }\end{array}$ & ITSP & $1,050,000$ & $150-200$ \\
\hline C & $\begin{array}{l}\text { Development of a } \\
\text { combustion techno- } \\
\text { logy based on cleaner } \\
\text { fuel }\end{array}$ & $\begin{array}{l}\text { Manager (Project } \\
\text { Coordinator) }\end{array}$ & ITSP & 828,000 & $<50$ \\
\hline D & $\begin{array}{l}\text { Development of car- } \\
\text { bon-reduction green } \\
\text { roof }\end{array}$ & $\begin{array}{l}\text { Director (Project } \\
\text { Coordinator) }\end{array}$ & SERAP & 382,000 & $<50$ \\
\hline
\end{tabular}

\section{Stage at Which Open Innovation is Applied}

According to the interviewees, open innovation has been applied at different stages of business operation, and R\&D is the stage where open innovation has been most rigorously applied. However, there are differences between large companies and small companies concerning the level of R\&D engagement. Amongst four companies interviewed, the large companies are inclined to collaborate with universities at the early R\&D stage, whereas the small companies tend to collaborate at the post R\&D stage. The large companies are seeking for information and competent technologies from universities through random search and regular attendance of university seminars. Once they have identified any technology developed by a university attractive to their own business, they will consider inviting the university to partner in R\&D. The large companies are also keen in recruiting graduates or students from the universities to support $\mathrm{R} \& \mathrm{D}$ projects. For the small companies, IUC is expressed in the form of equipment testing, third-party verification and technology assessment, through which the small companies capitalize on the research competence and reputation of universities to strengthen their R\&D capacity as well as their sales and marketing.

\section{Key Drivers to Open Innovation}

New business models for enhancing competitive advantage are emphasized by both large and small companies as a key driver to open innovation. However, these companies are aiming at different kinds of competitive advantage. The large companies are pursuing long-term competitive advantage in terms of a positive and trustful relationship with customers, as well as future business opportunities. In contrast, small companies are expecting direct benefits from IUC, e.g. the production/technology optimization through collaborating with competent and reputable partners; sharing of resources; and reputation management. 


\section{Key Barriers to Open Innovation}

The barriers encountered by the two large companies are simpler and easier to be handled than the other two small companies. Synchronization of R\&D cycle with universities and considerable time-spent in searching for right university partners are considered by both large companies as key unpredictable and uncontrollable impediments to open innovation. Small companies, however, are facing more serious blockades, including the lack of competence and resource for promoting IUC. In particular, they lack a bridging mechanism that helps them locate the relevant university partners, they barely possess any bargaining power with the university, and they are in a difficult position to secure support from investors.

\section{Major Stakeholders for Ideation and Innovation}

IUC environmental innovations are motivated by customers, competitors and regulators. Open innovation attempts by both large and small companies are mainly customer-driven. Companies collaborate and open innovate with universities proactively in order to take leads in the business markets.

\section{Influence of Company Size and Business Scale on the Company's Capability to Open Innovate}

Company size and business scale are critical factors affecting the companies capability to conduct IUC. The large companies are in a better position to connect with universities than the SMEs, because of their higher level of research competence and investment capital, and stronger networking capability; which make them more favored by the universities. Small companies, however, are in lack of a strong networking capability. They have great difficulty in connecting with the right university and collaborative research partner. Given their lack of the right expertise and proven innovation track record, it is very difficult, if not possible, for them to successfully convince universities to partner with them in start-up innovation projects.

\section{Discussion}

\section{Open Innovation Drives Competitive Advantage}

The quantitative results and case study findings confirm that there is general recognition among the industrial R\&D executives that open innovation, such as IUC in ITF-funded environmental projects, has enhanced their company's competitive advantage. The general agreement that competitive advantage has led to higher profitability and innovation competence reinforces the conception that open innovation provides a good opportunity for companies to gain competitive advantage (Chesbourgh, 2003, Chesbourgh et al., 2006). Interviews conducted with SMEs and large IUC companies have revealed that competitive advantage as a result of their engagement in IUC open innovation projects differ in dimensions. Whilst large companies cite the security of future business opportunities and maintenance of a continual positive relationship with clients/customers as two prominent areas of competitive advantage as a result of IUC-open innovation, SME companies have highlighted additional aspects such as product differentiation and profitability (see Section 4).

\section{Key Drivers for IUC Open Innovation}

Quantitative data shows that the development of an innovative and unique business model with the potential to enhance a company's competitive advantage tops the list of drivers for IUC-open innovation, technology complexity, and increasing customer demands for more in- 
novative products, as well as reputation management create considerable impetus for companies to take the open-innovation pathway by collaborating with universities (see Figure 2).

A closer look at the composition of the survey respondents reveals that the majority are SMEs (13 out of 16 companies). These companies are searching for innovative and unique business models to enhance their innovation capabilities, as SMEs generally lack such capabilities in house. Large and small companies look to universities for collaboration to enhance product differentiation and reputation management. Innovative products developed in partnership with universities are considered by clients/customers as more credible and reputable and therefore more competitive in the market (see Appendix Apart (b)). The drivers we identified are consistent with the findings from the literature review on drivers of IUC (see Section 1).

\section{Key Barriers to IUC Open Innovation}

SMEs are generally characterized by small size and capital ownership, lack of expertise and resources, and weak networking capability. Universities generally do not find them an attractive partner to work with (see Appendix A, part (e)). This explains why $50 \%$ of the survey respondents cited the unavailability of competent external partners to provide the necessary knowledge and technologies for open innovation as the key barrier to IUC (see Figure 3). University partners are often not readily available for partnership. SMEs also find it difficult to locate the right candidate for IUC, due to the lack of appropriate institutional mechanisms to match the industrial and university partners. SMEs often miss the opportunities for innovation because of their relatively weak networking capability. Furthermore, the fear of the disclosure of one's own intellectual property to external partners also created another major barrier ( $44 \%$ of agreement) for collaboration with universities in open innovation environmental projects (see Figure 3).

\section{Industry-University Collaboration: To Be or Not to Be}

Companies are keen to work with universities to acquire ideas and innovation. Universities have good mastery of knowledge and technology and good track records of research ethics, and are good observers of intellectual property rights. Even though the ITF-funded companies gained competitive advantage through collaboration with universities. the surveyed companies, in reality, seem to be hesitant with IUC. In fact, universities are often not the good partnership candidates. These companies prefer working with other external partners such as customers. As shown by the quantitative survey, customers (Mean Score $=3.5$ ) and law-makers (Mean Score $=3.1$ ) are more likely to be partners for ideas and innovations. The scores for universities (Mean Score $=2.9$ ) or research institutes (Mean Score $=2.7$ ) are consistently lower (see Figure 6). Companies, especially SMEs, find it hard to persuade universities for partnership because of their small size and scale of operation and innovation competence, the lack of investment funding, and weak networking capability.

\section{The Constraints of Local Industries under the Current Funding and Institutional Mechanisms for Technology and Innovation}

In Hong Kong, local industries can apply for funding support through various programmes under the Innovation and Technology Fund. The Small Entrepreneur Research Assistance Programme is specially set up to support SME innovation. As of 2011, a total of HK\$5798.8 million have been delegated to support 2,345 ITF-funded projects. However, only $6.3 \%$ is allocated to SMEs under the programme (Innovation and Technology Commission, 2011a). This is due to the restriction imposed that SMEs are required to contribute $50 \%$ of the project cost. The University-Industry Collaboration Programme mainly supports collaborative research projects that involve private companies engaging in commercial business as the applicant and 
the university as a partner. Again, $50 \%$ of the project cost is borne by the participating company (Innovation and Technology Commission, 2011b). Other funding schemes are mainly reserved for government-funded R\&D centres, academic institutions, or government-related organizations. Institutional mechanisms cannot really help industries partner with the most relevant university groups. In fact, it is usually the research institution that handpicks their collaborative partners. While large industrial companies have to rely on their own networks to search for the right candidates, small companies are generally at a big disadvantage (see Section 4).

\section{Policies and Institutional Arrangements for Promoting IUC}

In view of the above, two measures are necessary to move local industries out of the current deadlock to take advantage of IUC open-innovation. They include funding support for SMEs in technology development and innovation, and institutional mechanisms to help local industries locate the right university collaborators. Top innovative countries have focused on supporting SMEs for innovation. Government support mainly consists of monetary funding and the provision of technical know-how. In Germany, up to 450 million Euros was given to assist SMEs under the ZIM programme during 2009-10. Between 2006 and 2008, the Swedish Agency for Innovation Systems provided 36 million Euros to 360 SMEs through its "Research and Grow" programme to directly support innovation projects. Indirect support was provided to let SMEs have access to people with experience in innovation and R\&D. In 2006-2007, 67\% of the projects involved new collaborations with R\&D performers, universities, research institutes or other companies. In Denmark, direct and indirect support was given to support SME innovation. A "double-up" initiative started in 2008 with a funding of DKK 30 million plans to offer public co-financing of research projects between SMEs and academic and research institutions. Institutional mechanism was established to serve as the portal to help SME obtain knowledge from academic and research institutions. Other indirect support was given to SMEs by means of a mentorship scheme. The purpose was to loan experienced and competent industry managers to SMEs so as to provide them with the right competence and tools for innovation management and to help them develop right strategies leading to innovation (Capgemini Consulting, 2010) Direct funding support in the form of public co-financing of collaborative projects between industrial enterprises and academic institutions is a good strategy to encourage the local industries. It is especially helpful in engaging SMEs to participate IUC.

Promoting industry-academic linkage is a prominent trend across top innovative countries. This linkage is promoted in a number of ways, including: the promotion of commercialization in universities, the increasing of industrial PhDs co-supervised by industrial enterprises and universities, entrepreneurship education and technology incubators in universities. In Denmark, promoting the interaction between the research and industry communities are among the key foci of the Danish government. An action plan was developed by a Danish government institution to promote more innovation and effective knowledge dissemination during 2007-2010. The plan covered the SMEs and called for the strengthening of knowledge dissemination and interaction between the research community and industry (Capgemini Consulting, 2010).

\section{Conclusion}

Due to increasing global competition, Hong Kong's industries have to innovate to enhance their competitiveness in the long-term. 98.9\% of industries in Hong Kong are SMEs (Trade and Industry Department, HKSAR Government, 2011). They are characterized by their small scale of operation and weak innovation competence. Collaborating with universities is an attractive idea to strengthen their internal innovation capabilities. However, huge barriers exist.

Companies participating in ITF-funded environmental projects perceive definite competitive advantages through collaboration with universities, but find that universities are highly hesitant 
about collaborating with SMEs. Universities find SMEs unattractive due to their small size, limited capital, innovation competence and the lack of substantial benefits. For example, a company was able to secure a university partner to collaborate in a renewable energy project at the initial phase but the university subsequently declined to continue the partnership in the second phase.

Given the difficulties, it is vital for the Hong Kong government to investigate new ways of engaging local industries, especially the SMEs, in IU innovation projects, and provide relevant funding and institutional support. Overseas innovation experiences suggest that more direct funding support could be helpful, for instance, public co-financing of IU collaborative projects. The weak networking capability of the SMEs in Hong Kong can be improved by mentorship scheme and loaning experienced personnel, and providing a portal to share knowledge and expertise from academic and research institutes.

\section{Limitation of Study and Future Work}

Industry/Business surveys in Hong Kong generally receive low response rates. Our survey which focussed on the industry sector particularly, of the SMEs, is of no exception. Having said so, our survey response rate of $18 \%$ is considered to be relatively higher than other similar types of surveys conducted in Hong Kong. For instance, a 2005 survey conducted to SMEs to investigate the drivers and barriers for them to engage in voluntary environmental initiatives received a response rate of $5 \%$; the same survey distributed to the ISO14001 certified companies had a response rate of $12 \%$ (Studer et al., 2005). In 2011, an annual survey conducted by Hong Kong General Chamber of Commerce to Hong Kong businesses on business prospects, received a response rate of $11.1 \%$ (HKGCC, 2011). The low response rates for surveys targeting at the local industry or business has been a common phenomenon in Hong Kong, given a culture which does not lend much support to social science research and a high concern about confidentiality among the local business and industry respondents in Hong Kong.

This project constitutes part of our 2-year project on Open Innovation in the context of IUC. This project investigated the drivers and barriers to IUC in environmental (including clean energy) ITF-funded projects from the industry perspective. Our next phase of work will be focussing on the same issue from the university perspective. Correlation study between company background variables, including company size, total amount of R\&D investment and its ratio, and drivers and barriers in Open Innovation in the context of IUC will be conducted next phase. The study will also investigate in depth what policy measures can be used to improve IUC in technological environmental innovation in the context of Hong Kong, incorporating the feedback from IUC collaborators in ITF-funded projects.

\section{Acknowledgement}

The assistance of Miss Esther Wong in editing this article is gratefully acknowledged. All errors remain the authors. We would also like to gratefully acknowledge the funding support from the Small Project Funding (SPF-20090717621) and the University Development Fund awarded to the Initiative on Clean Energy and the Environment, the University of Hong Kong. 


\section{REFERENCES}

Capgemini Consulting, 2010, Benchmarking Study on Innovation Policy, CC India, Research Services.

Chesbrough, H.W., 2003, Open Innovation: The New Imperative for Creating and Profiting from Technology, Cambridge, Harvard Business School Publishing.

Chesbrough, H., W. Vanhaverbeke, and W. en West, J., 2006, Open Innovation: Researching a New Paradigm, Oxford University Press.

Fontana, R., Geuna, A., Matt, M., 2006, Factors affecting university-industry R\&D projects: The importance of searching, screening and signalling, Research Policy, 33, 309-323.

Herzdog, P., 2009, Innovation and the open innovation concept, Open and Closed Innovation: Different Cultures for Different Strategies, Gabler.

Hershberg, E., Nabeshima, K., Yusuf, S., 2007, Opening the ivory tower to business: universityindustry linkages and the development of knowledge-intensive clusters in Asian cities, World Development, 35, 6, 931-940, doi:10.1016/j.workddev.2006.05.006.

HKGCC (Hong Kong General Chamber of Commerce), 2011, Business Prospects Survey, http://www.chamber.org.hk/FileUpload/201112131706320266/BPS.pdf

Innovation and Technology Commission, HKSAR Government, 2011a, Innovation and Technology Fund Statistics of Approved Projects, http://www.itf.gov.hk/l-eng/Stat View101.asp

Innovation and Technology Commission, HKSAR Government, 2011b, About the Innovation and Technology Fund, http://www.itf.gov.hk/l-eng/about.asp

INSEAD, 2010, Global Innovation Index Report 2009-2010, INSEAD and India's Confederation Industry, http://www.globalinnovationindex.org/gii/main/reports/2009-10/FullReport_09-10.pdf

Laursen, K., Salter, A., 2004, Searching high and low: what types of firms use universities as a source of innovation? Research Policy, 33, 1201-1215.

Melese, T., Lin, S.M., Chang, J.L., Cohen, N.H., 2009, Open innovation networks between academia and industry: an imperative for breakthrough therapies, Nature Medicine, $15,5,502-507$.

Perkmann, M., Walsh, K., 2007, University-industry relationships and open innovation: Towards a research agenda, International Journal of Management Reviews, 9, 4, 259-280, doi:10.1111/ j.1468-2370.2007.00225.x.

Porter, M., 1998, Competitive Strategy, Free Press.

Schienstock, G., Hämäläinen, T., 2009, Transformation of the Finnish Innovation System: A network approach, Sitra Reports, Helsinki, Hakapaino Oy.

Studer, S., Welford, R., Hills, P., 2005, Drivers and Barriers to Engaging Small and MediumSized Companies in Voluntary Environmental Initiatives, The Centre of Urban Planning and Environmental Management, The University of Hong Kong, http://www0.hku.hk/kadinst/PDF_file/Report-final.pdf

Trade and Industry Department, HKSAR Government, 2011, Hong Kong: the Facts, http://www.gov.hk/en/about/abouthk/factsheets/docs/trade\&industry.pdf

Van Looy, B., Debackere, K., Andries, P., 2003, Policies to stimulate regional innovation capabilities via university-industry collaboration: an analysis and an assessment, $R \& D$ Management, 33, 2, 209-229, Blackwell Publishing Ltd. 


\section{Appendix A}

- With reference to four stages of business operation, at which stage was open innovation applied, namely, ideation, R\&D, marketing and sales, and post-sales? How did your company actually carry out IUC open innovation projects? Give an example to illustrate:

\begin{tabular}{|c|c|}
\hline Company & \\
\hline Large A & $\begin{array}{l}\text { Open innovation has been applied at all stages of business operations, although } \\
\text { R\&D is the stage during which open innovation is most utilized. } \\
\text { This is how we conduct industry-university collaboration: we have a specific tech- } \\
\text { nology in mind to be developed. Then we look for information and technologies } \\
\text { that fit our needs. During random visits and regular attendance of departmental } \\
\text { seminars, we collect information that is relevant to us. If we find certain technology } \\
\text { developed by the university attractive, we will then approach the relevant research } \\
\text { parties for partnership. } \\
\text { Another approach is through customer-driven innovation-customers first approach } \\
\text { us and give suggestions on how to improve their OEM or ODM products. We then } \\
\text { take this information and try to locate suitable university collaborators who can } \\
\text { provide the right type of capabilities to meet their needs. } \\
\text { Operationally, we recruit students from universities and invite them to work in } \\
\text { our company. R\&D will be conducted on a specific area through contractual } \\
\text { agreements, or by financing the research team to conduct R\&D in university } \\
\text { laboratories. }\end{array}$ \\
\hline Large B & $\begin{array}{l}\text { R\&D is the stage where open innovation has been rigorously performed. } \\
\text { We usually collaborate with universities through an internship programme-by } \\
\text { providing students with opportunities to work with our R\&D staff and to engage } \\
\text { in our innovation projects. }\end{array}$ \\
\hline SME C & $\begin{array}{l}\text { R\&D is the stage where open innovation has been rigorously performed. } \\
\text { As far as this ITF project is concerned, we first conducted internal modeling and } \\
\text { testing. But because we didn't have relevant testing equipment and relevant expertise } \\
\text { to conduct the test in a scientific way, we collaborated with a university and was } \\
\text { able to perform equipment testing in a more rigorous and scientific manner for } \\
\text { technology optimization. We also invited the university to conduct third-party } \\
\text { verification so that the technology we developed can obtain professional recognition } \\
\text { for next stage development. }\end{array}$ \\
\hline SME D & $\begin{array}{l}\text { keting and sales stage is the stage which involves significant open innovation. } \\
\text { ooperated with a university for technology endorsement and marketing. We } \\
\text { collaborated with another university to collect data that show additional be- } \\
\text { sof our environmental products. }\end{array}$ \\
\hline
\end{tabular}


- What are the key drivers for your company to adopt IUC-open innovation? Please give an example that IUC enhances your company's competitive advantage?

\begin{tabular}{|c|c|}
\hline mpany & \\
\hline Large A & $\begin{array}{l}\text { Key drivers include technology complexity, integration of external knowledge and } \\
\text { expertise, and new business model for enhancing competitive advantage. } \\
\text { We perceive long-term competitive advantage in terms of business opportunities } \\
\text { and a continual positive relationship with our customers. The gain from innovation } \\
\text { projects would not necessarily be direct profit return, though we did experience } \\
\text { increasing profits with successful projects. }\end{array}$ \\
\hline Large B & $\begin{array}{l}\text { Developing a new business model for enhancing competitive advantage is a key } \\
\text { driver for us to adopt IUC. } \\
\text { The major benefits include business trust and future business opportunity, and } \\
\text { long-term competitive advantage. }\end{array}$ \\
\hline SME C & $\begin{array}{l}\text { Key drivers include our vision to achieve better and quicker results on cleaner energy } \\
\text { production/technology optimization through collaborating with competent and } \\
\text { reputable partners; sharing of resources; and reputation management. } \\
\text { Competitive advantage is foreseeable mainly in terms of product differenti- } \\
\text { ation-more specifically, creating a new technology that gives a higher rate of energy } \\
\text { efficiency that is state of the art, innovative, and highly popular among an emerging } \\
\text { culture and market for cleaner energy, which also gives the expectation of higher } \\
\text { profitability for the company in the long run. }\end{array}$ \\
\hline SME D & $\begin{array}{l}\text { Key driver being the development of an innovative and unique business model with } \\
\text { the potential to increase our company's competitive advantage. } \\
\text { The project is still at the stage of development, so we cannot give examples that } \\
\text { IUC leads to competitive advantage. }\end{array}$ \\
\hline
\end{tabular}


- What are the key barriers for your company to adopt IUC-open innovation?

\begin{tabular}{|l|l|}
\hline Company & \\
\hline Large A & $\begin{array}{l}\text { Research is a random process. The process of searching for the right technology } \\
\text { for integration is time-consuming and the final outcome is highly uncertain and } \\
\text { unpredictable. A lot of time and capital investment is required before successful } \\
\text { yields. }\end{array}$ \\
\hline Large B & $\begin{array}{l}\text { IUC is time-consuming and comes with many uncontrollable factors. Students may } \\
\text { not have enough time to conduct collaborative R\&D through a short-term internship } \\
\text { programme. Extra time is spent on gearing up new collaborative partners and getting } \\
\text { them familiar with the research topic. }\end{array}$ \\
\hline SME C & $\begin{array}{l}\text { The absence of a strong research capability in-house, academic inertia to collaborate } \\
\text { with SMEs, lack of a bridging mechanism to help us speed up the searching process } \\
\text { for relevant university partners, weak bargaining power with the university, diffi- } \\
\text { culty in seeking investors to support innovation projects which involves high invest- } \\
\text { ment costs with returns not predictable and obtainable until the longer-term, or- } \\
\text { ganizational culture not supporting R\&D, existing government policy and funding } \\
\text { mechanism not supportive of SME-university collaboration in environmental in- } \\
\text { novation. }\end{array}$ \\
\hline SME D & $\begin{array}{l}\text { The lack of relevant competence in the university, technology easy to copy, no need } \\
\text { to rely on external partners, small business size-lack of manpower and resource } \\
\text { to investigate and devote in partnership, immature market and lack of incentive to } \\
\text { accelerate the innovation progress }\end{array}$ \\
\hline
\end{tabular}


- What are the major types of stakeholders that your company would frequently rely upon for ideas and innovation?

\begin{tabular}{|l|l|}
\hline Company & \\
\hline Large A & $\begin{array}{l}\text { The university is our major source of ideas and innovation, for two reasons: firstly, } \\
\text { universities have a good mastery of technology development and a higher chance } \\
\text { of success in process or product innovations. Second, clients will have a higher } \\
\text { confidence in doing business with us when they know our process/ product techno- } \\
\text { logies are developed in partnership with the universities. }\end{array}$ \\
\hline Large B & $\begin{array}{l}\text { We mainly rely on customers for ideas and innovation. This is because customers } \\
\text { are good indicators of market demands, and our customers make up a significant } \\
\text { portion of the market. They can easily steer the market directions and they are also } \\
\text { able to predict what sort of innovations are needed within the market. }\end{array}$ \\
\hline SME C & $\begin{array}{l}\text { We mainly rely on ourselves instead of other external parties, except for this special } \\
\text { collaborative project with a local university. It just happened by chance. }\end{array}$ \\
\hline SME D & $\begin{array}{l}\text { We mainly rely on customers, competitors and regulations for ideas and innovation. } \\
\text { We learn from our competitors and customers the sort of environmental and user- } \\
\text { friendly products they are looking for. With stringent environmental regulations } \\
\text { in place, we are able to develop new and innovative products that meet these re- } \\
\text { quirements. }\end{array}$ \\
\hline
\end{tabular}

- Would company size and business scale critically affect your company's capability to collaborate with universities? How and why?

\begin{tabular}{|l|l|}
\hline Company & \\
\hline Large A & $\begin{array}{l}\text { Size and scale are critical factors. It is much easier for larger companies to connect } \\
\text { with universities than SMEs, because of their higher level of expertise and invest- } \\
\text { ment capital, and stronger networking capability; this would give them more } \\
\text { chances to approach universities for partnership, and they have a stronger ability } \\
\text { to convince universities that they are decent partners to work with. }\end{array}$ \\
\hline Large B & $\begin{array}{l}\text { Larger size and scale of business definitely provides an advantage for collaborating } \\
\text { with universities, because of a better guarantee in the availability of funding, and } \\
\text { the ownership of stronger corporate governance-e.g. explicit and clear partnership } \\
\text { goals. }\end{array}$ \\
\hline SME C & $\begin{array}{l}\text { Smaller size is a definite obstacle to industry-university collaboration. With the } \\
\text { lack of expertise and track record in innovation, it is difficult for us to persuade } \\
\text { the university to partner with us in start-up projects. }\end{array}$ \\
\hline SME D & $\begin{array}{l}\text { Smaller size and scale somehow will affect industry-university collaboration. SMEs } \\
\text { do not have a strong networking capability and it is difficult for them to approach } \\
\text { the university and find the relevant professor/researcher to collaborate with them } \\
\text { for problem and solution identifications. But for our company, because I have de- } \\
\text { veloped a strong network and cooperation relationship with university professors, } \\
\text { we can easily approach them for collaboration. }\end{array}$ \\
\hline
\end{tabular}




\section{ABOUT THE AUTHORS}

Dr. Jacqueline Chi Kei Lam: Dr. Jacqueline Lam is the Research Assistant Professor of the Department of Electrical and Electronic Engineering, the University of Hong Kong. Her research covers three areas including: (1) conditions that govern the process of clean energy transitions in the society and the approaches for managing these transitions, (2) policies and strategies that can effectively stimulate the process of socio-technological change and their relative potentials, and (3) ways to engage the society and build trust for more effective energy governance. She has close connections with the industry, government and the society. Her work carries a strong element of university-industry collaboration, community education and outreach. Dr. Lam is the recipient of the 2012-13 university-wide Research Assistant Professorship, and also a core member of the open innovation network, Initiative on Clean Energy and Environment. Prior to joining the Department (2008-12), she was a teaching consultant and postdoctoral fellow of the Kadoorie Institute in HKU.

Prof. Peter Hills: Professor Peter Hills is the Director of Kadoorie Institute, the University of Hong Kong. His research interests centre on the relationship between environmental and sustainability issues and the policy-making process. Over the years, his personal research agenda has moved on from an early interest in transport-environment issues and applications of environmental impact assessment (EIA), to energy-environment problems and more recently to environmental policy processes, environmental governance, sustainable development and ecological modernisation. He has acted as a consultant to various international organizations, including The United Nations Development Programme, The United Nations Economic and Social Commission for Asia and the Pacific, The Asian Development Bank, The International Labour Office, The Asian and Pacific Development Centre, and The European Union. He has recently been working as a consultant for the EU-funded Urban Environmental Planning Programme Vietnam which has been assisting the Ho Chi Minh City University of Architecture to upgrade its urban planning programmes.

Clever K.W. Ng: Clever K.W. Ng holds a BBA from Sun Yat-sen University. Her fields of interest are Small and Medium Enterprises and the Environment in Hong Kong; Open Innovation; Social Enterprises in Hong Kong and Mainland China; Sustainability Studies. She has developed interest in Corporate Social Responsibility of SMEs and SEs since bachelor study in Sun Yat-sen University. She was deeply involved in environmental improvement projects and CSR-employees engagement for a SME company. Her recent research study focuses on open innovation especially on the university-industry collaboration in environmental and cleaner energy Innovation and Technology Fund-funded projects in Hong Kong. 
Copyright of International Journal of Technology, Knowledge \& Society is the property of Common Ground Publishing and its content may not be copied or emailed to multiple sites or posted to a listserv without the copyright holder's express written permission. However, users may print, download, or email articles for individual use. 